\title{
Społeczna percepcja wyborów w PRL w świetle listów nadesłanych do władz podczas konsultacji projektu nowej ordynacji wyborczej do Sejmu w 1985 roku
}

\begin{abstract}
Abstrakt: Artykuł prezentuje przegląd opinii, które zawierają listy przesłane władzom PRL podczas tzw. konsultacji społecznych projektu nowej ordynacji wyborczej do Sejmu w $1985 \mathrm{r}$. Większość nadawców pisała krytycznie nie tylko o samym projekcie, ale także o systemie wyborczym PRL w ogóle. Zestawiając te opinie ze znanymi z innych publikacji listami z okresu budowy w Polsce systemu komunistycznego, autor stawia tezę, iż przez kolejne dziesięciolecia trwania rządów PPR/PZPR Polacy nawet jeśli brali udział w powszechnych głosowaniach, zdawali sobie sprawę $\mathrm{z}$ ich fasadowego charakteru.
\end{abstract}

Słow a klu c z ow e: wybory w PRL, Polska Zjednoczona Partia Robotnicza, Sejm PRL, percepcja społeczna rządów komunistycznych w Polsce.

Abstract: The article presents a survey of opinions expressed in the letters sent to the authorities of the Polish People's Republic during the so-called social consultations of the draft of a new electoral law to the Sejm in 1985. A majority of people wrote critically not only about the project itself but also about the whole electoral system of the Polish People's Republic. After a comparison of these opinions with other letters known from the period of building of a communist system in Poland, the author puts forward a thesis that in the successive decades of the rule of the Polish Workers' Party/Polish United Workers' Party, even if they had voted in universal elections, the Polish people were aware of their window-dressing nature.

Keyw ords: elections in People's Poland, Polish United Workers' Party, Polish Sejm, social perception of the communist regime in Poland. 
Przez blisko pół wieku rządów komunistycznych w Polsce ani razu nie przeprowadzono powszechnego głosowania, które spełniałoby standardy demokratyczne ${ }^{1}$. Fałszerstwa wyborcze zastosowane przez PPR podczas tzw. referendum ludowego w $1946 \mathrm{r}$. oraz wyborów do Sejmu Ustawodawczego w 1947 r. były szczególnie rażące ${ }^{2}$. W kolejnych latach kierownictwo partyjno-państwowe przykładało już większą wagę do zachowania pozorów. Przepisy prawa miały demokratyczny wydźwięk, zaś zgodności rozmaitych działań związanych z organizacją wyborów z litera prawa pilnowali inspektorzy Państwowej Komisji Wyborczej. Ich zadaniem było wykrywanie i prostowanie przypadków łamania przepisów ordynacji. Za tą wyborczą fasadą kryły się jednak nieformalne praktyki, które zapewniały liderom PZPR całkowita kontrolę nad składem Sejmu PRL i ogłaszanie po każdym głosowaniu do 1980 r. niemal 100\% frekwencji: staranny dobór ludzi, których angażowano $\mathrm{w}$ prace w komisjach wyborczych różnych szczebli, rejestrowanie w każdym okręgu wyborczym tylko jednej listy kandydatów (w różnych latach opatrzonej

${ }^{1}$ Szerzej zob. M. Siedziako, Bez wyboru. Gtosowania do Sejmu PRL (1952-1989), Warszawa 2018. Tam również aktualny przegląd literatury przedmiotu. Niniejszy tekst oparty został na wynikach badań, których podsumowanie stanowi przywoływana monografia. Podczas prac nad książką nie wykorzystałem jednak wszystkich materiałów, zebranych w trakcie kwerend archiwalnych, które omawiam w niniejszym szkicu.

${ }^{2}$ Dostrzegali to także niektórzy działacze Polskiej Partii Robotniczej (PPR). „Komitet Łódzki czy komisja wyborcza - wspominała przykładowo po latach referendum z 1946 r. Celina Budzyńska - zajęła dużą aulę szkoły, gdzie aktyw segregował kartki. «3 razy nie» zjeżdżały do pieca w piwnicy, a aktyw pilnie wpisywał «3 razy tak». Było mi bardzo markotnie, wprawdzie od najmłodszych lat wpajano mi przekonanie, że cel uświęca środki, i że my partia - lepiej wiemy, co jest dobre dla kraju, dla narodu, że socjalizm - to cel najwyższy. Nie pamiętam, bym miała jakieś wątpliwości, że tej władzy - która przeprowadziła reformę rolna, zlikwidowała bezrobocie, odbudowuje kraj z ruin i zgliszcz - trzeba bronić. Ale wstyd mi było, że trzeba jej bronić przy pomocy szachrajstwa, oszukaństwa. Z ciężkim sercem siedziałam samotnie w gabinecie dyrektorskim na parterze (nikogo z kierownictwa szkoły nie było). Nagle wszedł stary Niemiec palacz i trochę słowami, trochę gestami zmusił mnie do odwrócenia się i spojrzenia w okno: nad dziedzińcem wirowało tysiące sczerniałych, niedopalonych skrawków papieru. Wiatr rozwiewał te «3 razy nie» hen, nad ulica Wólczańska, słońce oświetlało ten pierwszy protest społeczny przeciwko narzuconej, niechcianej władzy" (C. Budzyńska, Strzepy rodzinnej sagi, Warszawa 1997, s. 463). Wydaje się, że w kręgach kierowniczych PPR, a następnie PZPR bardziej powszechny był jednak stosunek do wyborów, który zaprezentował w rozmowach z Teresa Torańska, prowadzonych w latach 1982-1984, Jakub Berman. Twierdził on wówczas, że ani w latach czterdziestych, ani osiemdziesiątych polscy komuniści „nie mieli komu przekazać władzy”. Odnosząc się do początków rządów komunistycznych w Polsce, mówił: „A komu mieliśmy przekazać władzę?! Może Mikołajczykowi?! Albo stojącym bardziej na prawo od Mikołajczyka? Albo diabli wiedzą komu jeszcze? Pani mi zaraz powie, że byłoby to uszanowanie demokracji. I co z tego? Komu potrzebna taka demokracja! Teraz zresztą także nie możemy robić wolnych wyborów, nawet bardziej teraz niż 10 czy 20 lat temu, bo przegramy. Nie mam co do tego wątpliwości. Więc jaki sens mają takie wybory? Chyba że chcielibyśmy okazać się takimi ultrademokratami, takimi dżentelmenami, zdjać cylindry z głów, ukłonić się, powiedzieć: proszę bardzo, idziemy na odpoczynek, bierzcie sobie władzę”. T. Torańska, Oni, Warszawa 1989, s. 94. 
szyldem Frontu Narodowego/ Frontu Jedności Narodu [FJN]/ Patriotycznego Ruchu Odrodzenia Narodowego [PRON]), zaliczanie głosów oddawanych „bez skreśleń” (na co nieustannie naciskano) na konto kandydatów zamieszczanych na tzw. miejscach mandatowych oraz stosowanie różnego rodzaju innych manipulacji i zwyczajnych fałszerstw wyborczych (aczkolwiek wydaje się, że te ostatnie miały jedynie „korygujacy” charakter) ${ }^{3}$. W całej historii PRL (wyłączając tzw. wybory kontraktowe z 1989 r.) tylko raz zdarzył się przypadek, że posłem nie został kandydat przewidziany do tej roli, zamieszczony przez partię na tzw. miejscu mandatowym listy FJN w okręgu wyborczym nr 37 z siedzibą w Nowym Sączu w 1957 r.

Propaganda stosowana przez władze nieustannie głosiła wyższość wyborów w PRL nad wyborami, które przeprowadzano w krajach Zachodu oraz głosowaniami powszechnymi w II Rzeczypospolitej. Wybory w Polsce pod rządami PZPR miały być kwintesencja demokracji, nieustannie zresztą umacnianej. Była to oczywista fikcja, z której znaczna część obywateli zdawała sobie sprawę. Choć władzom, dzięki stosowaniu rozmaitych instrumentów nacisku (zarówno propagandy, jak i represji), udawało się skłaniać znaczącą część społeczeństwa do uczestnictwa w kolejnych wyborach, zawsze odnotowywano też głosy krytyczne. Nie można było ich jednak formułować publicznie, stanowiłoby to bowiem, używając określenia Hanny Świdy-Ziemby, naruszenie fasady traktowanej jak sacrum. „Gdyby ktoś chciał - pisała rzeczona badaczka - nadać fasadzie rzeczywistą treść czy odwrotnie - ujawnić rzeczywistą treść obowiąujących reguł, dokonałby zamachu na istotnościowe zasady funkcjonowania systemu"4.

W kolejnych kampaniach wyborczych różnego rodzaju formy oporu starali się wykrywać i zwalczać funkcjonariusze aparatu represji. Ich aktywność była szczególnie intensywna podczas dwóch wspomnianych głosowań w latach czterdziestych oraz przed wyborami do Sejmu PRL I kadencji w 1952 r. ${ }^{5}$ Później istotną rolę w wymuszeniu na obywatelach oczekiwanych przez władze zachowań wyborczych odgrywał już raczej sam strach przed represjami (umiejętnie przez rządzących podsycany ${ }^{6}$ ), wykształcony w społeczeństwie

${ }^{3}$ Szerzej na ten temat zob. M. Siedziako, Manipulacje i fatszerstwa wyborcze $w$ wyborach do Sejmu PRL (1952-1985), „Pamięć i Sprawiedliwość” 2016, nr 1 (27), s. 112-139.

${ }^{4} \mathrm{H}$. Świda-Ziemba, Człowiek wewnętrznie zniewolony. Problemy psychosocjologiczne minionej formacji, Warszawa 1998, s. 81-82.

${ }^{5}$ Szerzej zob. A. Zaćmiński, „Identyfikacja wroga” w wyborach do Sejmu PRL z 26 października 1952 r. - metodologia pracy Ministerstwa Bezpieczeństwa Publicznego, w: Wybory i referenda $w$ PRL, red. S. Ligarski, M. Siedziako, Szczecin 2014, s. 123-147.

${ }^{6}$ Na naradzie z pierwszymi sekretarzami komitetów wojewódzkich PZPR w kwietniu $1961 \mathrm{r}$. Władysław Gomułka radził przykładowo, aby w celu zwiększenia frekwencji doklejać na plakatach i obwieszczeniach wyborczych „anonimowe” dopiski o treści: „kto nie głosuje ten na liście figuruje”. „Wyborca sobie pomyśli - tłumaczył swój pomysł zgromadzonym - może na liście podatkowej, albo do redukcji? Taki maleńki maszynopis można gdzieniegdzie przylepić, nic w tym złego". Cyt. za: J. Olejniczak, Wybory do Sejmu i rad narodowych w okresie rzadów Wtadystawa Gomutki, w: Wybory i referenda..., s. 166. 
w okresie stalinizmu, niż rzeczywiste represje. Niemniej jednak Służba Bezpieczeństwa (SB) wciąż zbierała informacje, odnotowując krytyczne głosy o kolejnych wyborach, ale też różnego rodzaju „antywyborcze” zachowania ${ }^{7}$. Szczególnie wiele tego rodzaju działań zaczęło pojawiać się od 1980 r., kiedy w kraju funkcjonowała już zorganizowana opozycja demokratyczna ${ }^{8}$.

Dokumentacja SB, przechowywana w archiwach Instytutu Pamięci Narodowej, stanowi ważne źródło do poznania rzeczywistego stosunku Polaków do głosowań powszechnych w czasach rządów komunistycznych, nie jest to jednak źródło jedyne. Wielu informacji na ten temat dostarcza również lektura dzienników różnych osobistości - bacznych obserwatorów lub uczestników życia politycznego w Polsce w powojennym półwieczu. Ciekawe opisy praktyk wyborczych i percepcji społecznej wyborów w PRL można odnaleźć np. w opublikowanych dziennikach Stefana Kisielewskiego, Marii Dąbrowskiej, Jana Józefa Lipskiego, Janusza Zabłockiego, Jerzego Zawieyskiego, prymasa Stefana Wyszyńskiego czy Mieczysława F. Rakowskiego9.

Tyle razy to widziałem - pisał przykładowo po wyborach w 1976 r. Kisielewski a ciagle rzecz wydaje mi się niepojęta i nieprawdopodobna. W telewizji pokazuja, jak całe wsie ida „do urny” z kapela, jak głosuja „intelektualiści”, aktorzy, etc., bez przerwy powtarza się, że to ogromny sukces, że głosuje się za „lepszym jutrem”,

${ }^{7}$ Szerzej zob. m.in.: T. Danilecki, Formy oporu społecznego zwiazanego z wyborami powszechnymi w Polsce w okresie „matej stabilizacji”- zarys problematyki, „Pamięć i Sprawiedliwość” 2012, nr 1 (19), s. 107-134; Z. Bereszyński, Wybory w latach 1972-1989 oraz referendum społeczne w 1987 r. na Ślasku Opolskim. Działania aparatu władzy i środowisk opozycyjnych, akcje antywyborcze oraz spontaniczne przejawy postaw opozycyjnych wśród mieszkańców regionu, w: Wybory i referenda..., s. 263-332; S. Ligarski, Społeczeństwo polskie wobec wyborów do sejmu w 1976 i 1980 roku, w: Opozycja demokratyczna $w$ PRL w latach 1976-1981, red. W. Polak, J. Kufel, P. Ruchlewski, Gdańsk 2012, s. 328-348; M. Siedziako, Partia wybiera, społeczeństwo głosuje. Jak wytaniano Sejm PRL (1952-1985), w: Elity komunistyczne $w$ Polsce, red. M. Szumiło, M. Żukowski, Warszawa-Lublin 2015, s. 214-218.

${ }^{8} \mathrm{Na}$ temat działań podejmowanych przez opozycję demokratyczną w związku z wyborami do Sejmu PRL i rad narodowych w latach osiemdziesiątych szerzej zob. m.in. artykuły Kamila Dworaczka, Krzysztofa Brzechczyna, Grzegorza Waligóry, Wojciecha Polaka i ks. Jarosława Wasowicza SDB w tomie: Wybory i referenda..., s. 665-762, a także: O wolne wybory $w$ PRL. Zbiór dokumentów (1980-1989), wstęp A. Pleśniar, Wrocław 1989; A. Friszke, Czas KOR-u. Jacek Kuroń a geneza Solidarności, Kraków 2011, s. 474-482; G. Waligóra, Ruch Obrony Praw Człowieka i Obywatela 1977-1981, Warszawa 2006, s. 242-246; W. Polak, Bojkot wyborów do sejmu i rad narodowych $w$ regionie toruńskim $w$ latach 1984-1988, w: O Polskę wolna! O Polskę solidarna! NSZZ Solidarność w latach 1980-1989, red. W. Polak i in., Gdańsk 2011, s. 193-207.

9 S. Kisielewski, Dzienniki, Warszawa 2001; M. Dabrowska, Dzienniki. 1914-1965, t. I-XIII, oprac. W. Starska-Żakowska, Warszawa 2009; J.J. Lipski, Dzienniki 1954-1957, przedm. A. Friszke, oprac. Ł. Garbal, Warszawa 2010; J. Zabłocki, Dzienniki 1956-1986, t. I-III, wstęp J. Żaryn, oprac. M. Barcikowski i in., Warszawa 2008-2013; J. Zawieyski, Dzienniki, t. I: Wybór z lat 1955-1959, t. II: Wybór z lat 1960-1969, wybór i oprac. A. Knyt i in., Warszawa 2011-2012; S. Wyszyński, Pro Memoria, t. I: 1948-1952, red. P. Skibiński, Warszawa 2017; M.F. Rakowski, Dzienniki polityczne 1958-1990, [t. I-X], Warszawa 1998-2005. 
za przyszłością Polski, za owym, ale nikt nie bąknie słówka na temat, o którym wszyscy doskonale wiedzą: że to nie sa żadne wybory, lecz upokarzająca komedia, bo kandydaci sa z góry wyznaczenia i mianowani ${ }^{10}$.

W tym samym roku Rakowski zanotował: „21 marca odbyły się wybory do Sejmu. Przebiegały w atmosferze wyjątkowego braku zainteresowania. Ludzie wiedza, że jest to rytuał, w którym trzeba uczestniczyć. W gruncie rzeczy wiedzą o tym również rządzacy i na ich dobro należy zapisać, że nie kazali aparatowi wysilać się w okresie tzw. kampanii przedwyborczej"11.

Szerszy ogląd opinii Polaków na temat wyborów przeprowadzanych w PRL umożliwia analiza różnego rodzaju korespondencji - zarówno listów prywatnych wysyłanych między obywatelami (których treść możemy poznać $\mathrm{z}$ dokumentacji pozostawionej przez wyspecjalizowane w perlustracji korespondencji komórki aparatu represji), jak intencjonalnie (aczkolwiek często anonimowo) kierowanych do przedstawicieli władz. Tego rodzaju materiały $\mathrm{w}$ odniesieniu do pierwszych lat rządów komunistycznych w Polsce zaprezentowali w swojej pracy Tadeusz Wolsza i Andrzej Zaćmiński ${ }^{12}$, zaś Michał Skoczylas opublikował monografię opartą na skargach obywateli w związku z wyborami do Sejmu Ustawodawczego w 1947 r. ${ }^{13}$ Lektura rzeczonych publikacji prowadzi do wniosku, że większość ludzi trzeźwo oceniała wówczas sytuację polityczna, nie dając się zwieść głoszonym przez nowe władze hasłom o wolności, demokracji i sprawiedliwości społecznej. Obywatele zdawali sobie sprawę, że głosowania organizowane przez PPR/PZPR w latach 1946, 1947 i 1952 miały fikcyjny charakter, spełniając przede wszystkim rolę propagandowa. „Przecież doskonale sobie sprawę zdajemy, że wstawili nam lipę"14 - stwierdził dobitnie jeden $\mathrm{z}$ autorów listów, opublikowanych przez Wolszę i Zaćmińskiego, po ogłoszeniu wyników referendum z 1946 r.

Niezmiernie ciekawe materiały o podobnej proweniencji, aczkolwiek wytworzone już w schyłkowym okresie PRL, odnaleźć można w Archiwum Prezydenta RP, w zespole akt Kancelarii Rady Państwa (KRP). Chodzi

${ }_{10}$ S. Kisielewski, op. cit., s. 642.

${ }^{11}$ M.F. Rakowski, op. cit., [t. VI], s. 52. Rakowski sam brał udział w rzeczonej kampanii wyborczej jako kandydat na posła. Cytując jego zapiski, należy pamiętać, że autor zmieniał je, przygotowując do druku. Andrzej Paczkowski, który miał możliwość zapoznania się z ich maszynopisem, stwierdził: „Dzienniki polityczne mają podwójną naturę: są częściowo (w większości) autentycznymi zapiskami, które powstały równocześnie z opisywanymi wydarzeniami, a częściowo rodzajem wspomaganych źródłami wspomnień ubranych w formę dziennika. Myślę, że stan taki nie dyskwalifikuje tego opus magnum Rakowskiego, nakazuje jednak pewną ostrożność w korzystaniu z niego dla celów badawczych". A. Paczkowski, Pułapki „Dzienników” Rakowskiego, „Polityka” 2013, nr 15.

12 T. Wolsza, A. Zaćmiński, Ludzie listy pisza... Referendum i wybory do Sejmu w korespondencji Polaków (1946-1952), Bydgoszcz 2013.

${ }^{13}$ M. Skoczylas, Wybory do Sejmu Ustawodawczego z 19 stycznia 1947 r. w świetle skarg ludności, Warszawa 2003.

${ }^{14}$ Cyt. za: T. Wolsza, A. Zaćmiński, op. cit., s. 78. 
mianowicie o korespondencję kierowaną do władz w 1985 r., dotycząca ogłoszonych w styczniu tego roku do tzw. konsultacji społecznych założeń nowej ordynacji wyborczej do Sejmu PRL. Wraz ze wspomniana korespondencja z lat czterdziestych i początku lat pięćdziesiątych spinają one okres rządów komunistycznych $\mathrm{w}$ Polsce $\mathrm{w}$ swoista klamrę. Z jednej strony mamy do czynienia z materiałami z czasów budowy i umacniania dyktatury komunistycznej nad Wisła, z drugiej - z jej okresu schyłkowego. Dzięki dokonaniu takiego zestawienia możemy dowiedzieć się i ocenić, czy doskonalone przez lata przez komunistów manipulacje wyborcze i rozmaite zabiegi socjotechniczne zmieniły poglądy Polaków na temat urządzanych w PRL głosowań na przestrzeni kilkudziesięciu lat rządów PZPR. Innymi słowy - możemy zweryfikować, czy polskim komunistom udało się wmówić społeczeństwu, że propagandowe przedstawienie wyborów to rzeczywistość.

Oczywiście podkreślić należy, że lata stalinizmu ${ }^{15}$ oraz lata osiemdziesiąte to dwie zupełnie różne epoki w dziejach PRL. W latach czterdziestych i pierwszej połowie lat pięćdziesiątych ogromną rolę odgrywał strach przed represjami ${ }^{16}$. Wielu ludzi nawet $\mathrm{w}$ prywatnej korespondencji unikało krytykowania władz wprost, pisało w sposób zawoalowany. Choć sytuacja wydawała się niepewna (rozpowszechnione było np. oczekiwanie na kolejny, światowy konflikt zbrojny, atmosfera tymczasowości utrzymywała się na poniemieckich terenach przejętych przez Polskę, których nowa przynależność państwowa nie została potwierdzona traktatem międzynarodowym), z miesiąca na miesiąc nowy system władzy umacniał się, rozbudowując struktury aparatu represji

15 Pisząc o stalinizmie $\mathrm{w}$ odniesieniu do historii Polski, mam na myśli lata 1944-1956, biorac pod uwagę to, co stwierdził na ten temat Jerzy Eisler. „Osobiście - pisał rzeczony badacz - nie mam w tym względzie najmniejszych wątpliwości i uważam, że określenie «stalinizm» w przypadku Polski może i powinno być łączone z latami 1944-1956. Wyodrębnianie z tego okresu lat 1948-1955 ma zwykle podtekst polityczny i niejednokrotnie służy utrwalaniu mitu niemal demokratycznych początków "władzy ludowej» z lat 1944-1947. Wtedy - słyszymy - funkcjonował system wielopartyjny, dość szeroki był zakres swobody wypowiedzi, istniała jeszcze gospodarka trójsektorowa (sektory: państwowy, spółdzielczy i prywatny), nie podejmowano kolektywizacji rolnictwa i nie atakowano otwarcie Kościoła katolickiego. Wszyscy, którzy utrzymuja, że stalinizm w Polsce zaczął się dopiero w $1948 \mathrm{r}$. wraz z odsunięciem Gomułki z zajmowanych stanowisk i objęciem pełni władzy przez Bieruta i skupionych wokół niego "stalinowców», świadomie lub nie, przyczyniają się do utrwalenia tego mitu. Gomułka [...] przecież także był «stalinowcem» i odegrał ważną rolę w pierwszych latach «władzy ludowej», kiedy, wbrew przeświadczeniu wielu ludzi, terror był znacznie bardziej brutalny niż po 1948 r., kiedy faktycznie nabrał rozpędu proces sowietyzacji Polski. Główna różnica polegała na tym, że do 1948 r. terror wymierzony był w zadeklarowanych przeciwników nowej władzy: przede wszystkim w żołnierzy podziemia niepodległościowego i działaczy opozycyjnych partii, w tym zwłaszcza PSL. Potem natomiast stał się wszechogarniajacy i jego ofiarami mogli być w praktyce wszyscy ludzie”. J. Eisler, Siedmiu wspaniatych. Poczet pierwszych sekretarzy KC PZPR, Warszawa 2014, s. 76-77.

${ }_{16}$ Szerzej zob. M. Zaremba, Wielka trwoga. Polska 1944-1947. Ludowa reakcja na kryzys, Kraków 2012, s. 369-403. 
i przenosząc nad Wisłę radzieckie wzorce. Sytuacja w latach osiemdziesiątych była już zupełnie inna. Od lata 1980 r. trwał permanentny, wielowymiarowy kryzys systemu, z którym ekipa gen. Wojciecha Jaruzelskiego próbowała sobie poradzić różnymi sposobami. 13 XII 1981 r. wprowadzono stan wojenny, którego drakońskie prawa mogły nasuwać skojarzenia z okresem stalinowskim. Po jego zawieszeniu z końcem 1982 r., a następnie zniesieniu 22 VII 1983 r. w społeczeństwie polskim atmosfera strachu i obaw przed represjami stopniowo jednak opadała, zastępował ją nastrój marazmu i braku nadziei na poprawę bytu ${ }^{17}$. Władzom udało się rozbić wielomilionowy Niezależny Samorządny Związek Zawodowy (NSZZ) „Solidarność”, ale szybko został on zastapiony przez sieć podziemnych struktur, które swoją aktywnością podtrzymywały w społeczeństwie opór wobec reżimu komunistycznego. Tymczasem jednym z głównych celów, które próbowały osiagnąć władze, była swoista „relegitymizacja" niedemokratycznych rządów ${ }^{18}$.

W katalog licznych zabiegów, które miały przekonać społeczeństwo do poparcia władz $\mathrm{w}$ połowie lat osiemdziesiątych, wpisywała się reforma systemu wyborczego. Najpierw, w 1984 r., zmieniono ordynację wyborcza obowiąująca w wyborach do rad narodowych, które odbyły się w czerwcu tego roku. Główną zmianą było to, że o każdy mandat radnego ubiegało się dwóch pretendentów. Ponieważ utrzymano przy tym preferencyjny układ kandydatów na listach oraz praktykę głosowania bez skreśleń, wybory radnych pozostały propagandowym rytuałem. Po raz pierwszy w historii rządów PZPR oficjalna frekwencja wyniosła natomiast znaczaco poniżej tradycyjnych blisko $100 \%: 74,95 \%$ w wyborach do rad szczebla wojewódzkiego, $72,61 \%$ - do rad miejskich, $66,82 \%$ - do rad dzielnicowych i 77,9\% - do rad gminnych ${ }^{19}$. Tak niskie, jak na realia PRL, wyniki były ewidentnym wyrazem kryzysu, tymczasem władze uparcie lansowały hasło „normalizacji” 20.

Kolejna reforma prawa wyborczego, mająca stanowić wyraz „socjalistycznej demokratyzacji”, poprzedziła wybory do Sejmu PRL IX kadencji21.

${ }^{17}$ Idem, Klimat emocjonalny $w$ Polsce lat osiemdziesiatych. Studium na podstawie raportów Biura „W”, w: Społeczeństwo polskie w latach 1980-1989, red. N. Jarska, J. Olaszek, Warszawa 2015, s. 29.

${ }_{18}$ P. Kowal, Koniec systemu władzy. Polityka ekipy gen. Wojciecha Jaruzelskiego w latach 1986-1989, Warszawa 2012, s. 17-21.

${ }^{19}$ L. Mażewski, Posttotalitarny autorytaryzm PRL 1956-1989. Analiza ustrojowopolityczna, Warszawa-Biała Podlaska 2011, s. 128-131. Szerzej zob. J. Raciborski, J.J. Wiatr, Wybory w PRL. Doświadczenia i wnioski, Warszawa 1987, passim.

${ }_{20}$ Por. J. Rupnik, The Military and „Normalisation” in Poland, w: Eastern Europe. Political Crisis and Legitimation, ed. P.G. Lewis, London-Sydney 1984, s. 170-172.

${ }^{21}$ Według konstytucyjnych terminów powinny były odbyć się one wiosną $1984 \mathrm{r}$. W lutym tego roku, w warunkach trwającego kryzysu, Sejm PRL podją jednak decyzję o przedłużeniu swojej VIII kadencji na czas nieokreślony. Kazimierz Barcikowski uzasadniając na forum izby projekt ustawy konstytucyjnej w tej sprawie, stwierdził, że wybory trzeba zorganizować „w takim czasie, aby nie zostały zakłócone działania na rzecz odnowy i porozumienia, 
Pozory demokratycznych procedur starano się stworzyć już podczas prac nad projektem nowej ordynacji. W styczniu 1985 r. ogłoszono publicznie założenia do projektu ustawy, które miały następnie zostać poddane szerokim konsultacjom społecznym. Ciężar przeprowadzenia tej akcji spoczał na ogniwach $\mathrm{PRON}^{22}$. W zebraniach konsultacyjnych miało wziać udział ponad milion obywateli ${ }^{23}$, ale władze oceniały, że zainteresowanie nimi było „stosunkowo niewielkie” ${ }^{24}$. Atmosfera tego rodzaju zebrań w PRL nigdy nie sprzyjała swobodnemu wyrażaniu opinii. Przebiegały one w myśl określonego scenariusza, według utartych schematów ${ }^{25}$. Do władz wpłynęło jednak także

znajdujące swoje odbicie m.in. w pracach ustawodawczych" (Biblioteka Sejmowa w Warszawie, Sprawozdania stenograficzne posiedzeń Sejmu PRL, II-12634, Sprawozdanie stenograficzne z 46 posiedzenia Sejmu Polskiej Rzeczypospolitej Ludowej w dniu 26 stycznia 1984 r., Warszawa 1984, k. 6). Dopiero w grudniu 1984 r. posłowie przegłosowali ustawę konstytucyjna, która jako termin upływu trwającej kadencji Sejmu wyznaczała 31 sierpnia 1985 r. (Ustawa konstytucyjna z dnia 3 grudnia 1984 r. o terminie upływu kadencji Sejmu Polskiej Rzeczypospolitej Ludowej, DzU 1984, nr 55, poz. 279). Kolejne wybory sejmowe miały stać się głównym wydarzeniem politycznym drugiej połowy 1985 r. i stanowić „doniosły akt zamykajacy okres kryzysowy w sferze politycznej”. Archiwum Akt Nowych (dalej: AAN), Komitet Centralny Polskiej Zjednoczonej Partii Robotniczej (dalej: KC PZPR), V/265, Prognoza rozwoju sytuacji społeczno-politycznej w kraju do końca 1985 roku opracowana przez Międzywydziałowy Zespół KC PZPR z udziałem przedstawicieli: GZP WP, MSW, Urzędu ds. Wyznań oraz OBOPiSP, CBOS i PAP, Warszawa, maj 1985 r., k. 254.

${ }^{22}$ PRON zajał miejsce skompromitowanego FJN w 1983 r., spełniał jednak równie fasadową rolę. Szerzej zob. M. Przeperski, PRON - nowy pas transmisyjny. Przyczynek do nacjonalistycznej próby legitymizacji ustroju w poczatku lat 80., „Studia Migracyjne - Przegląd Polonijny" 2010, z. 1 (135), s. 51-80.

${ }^{23}$ Archiwum Prezydenta RP (dalej: APRP), Kancelaria Rady Państwa (dalej: KRP), „Wybory do Sejmu 1985 r. Materiały z konsultacji nowej ordynacji wyborczej, przeprowadzonej przez PRON" (stara sygn. Archiwum Kancelarii Rady Państwa: 940/1), Pismo sekretarza generalnego RK PRON Jerzego Jaskierni i przewodniczącego RK PRON Jana Dobraczyńskiego do przewodniczącego Rady Państwa Henryka Jabłońskiego, Warszawa, 20 III 1985 r., k. 5.

${ }^{24}$ K.B. Janowski, Źródła i przebieg zmiany politycznej w Polsce 1980-1989. Studium historyczno-politologiczne, Torun 2004, s. 159.

${ }^{25} \mathrm{~W}$ jednym z listów przesłanych do KRP w okresie konsultacji, podpisanym przez ośmiu mieszkańców Wrocławia, możemy nawet odnaleźć informację, iż w komitecie PRON odmówiono przyjęcia uwag. Ludwik Wąsowski, Michał Budzian, Hieronim Kukta, Jacek Rudziński, Edmund Cholewa, Wiktor Rycyk, Wacław Kotowski i Tadeusz Szurzyński pisali: „Chociaż wiemy, że nasz udział w dyskusji nad projektem ordynacji wyborczej do Sejmu - jest rzucaniem grochem o ścianę, gdyż żadna władza totalitarna nie wysłuchuje społeczeństwa, to jednak niech przynajmniej wie, że od 1945 r. po dzień dzisiejszy nie miała legitymacji i mieć nie będzie. Byliśmy w PRON dla podania swoich postulatów do ordynacji. Niestety tych postulatów nie chciano przyjąć. Stąd mamy tylko jeden wniosek, że PRON to stary FJN podobnie inspirowany, kierowany i nadzorowany przez PZPR. Pozostali sygnatariusze PRON - to satelici PZPR. Totalitaryzm to rządy komunistów bądź faszystów - my jesteśmy demokratami, a totalitaryzm nie znosi demokracji, nie lubi być kontrolowany przez społeczeństwo, siebie nazywa demokracja, chociaż z demokracją nie ma nic wspólnego". Dalej autorzy przedstawiali swoje propozycje do projektu, postulując m.in., aby głosy 
kilkaset listów, których nadawcy wyrażali swoje opinie zarówno na temat planowanych zmian w prawie, jak i praktyk wyborczych PRL w ogóle.

Powszechnie krytykowano praktyki stosowane w dotychczasowych głosowaniach, stanowiace podstawowe instrumenty kontroli PZPR nad przebiegiem wyborów i składem Sejmu, w tym przede wszystkim blokowanie zgłaszania niezależnych kandydatów, narzucanie jawnego głosowania „bez skreśleń” i przyznawanie kandydatom zamieszczonym na tzw. miejscach mandatowych oddanych w ten sposób głosów.

Pierwsza część [wyborów, czyli układanie list kandydatów - M.S.] - pisał w liście przesłanym do Kancelarii Rady Państwa Marek Łukaszewski z Wrocławia - nie może być dla obywatela czarna magia, nie można układać list w zacisznych gabinetach bez wiedzy wyborców. Osobiście czuję się manipulowany, jeżeli nie mam żadnego wpływu na ułożenie listy kandydatów i jeżeli o wyborze decyduje kolejność kandydatów na liście (a nie wybranie przez skreślenia). W sytuacji listy kandydatów, na której miejsce decyduje o wyborze i do której nie mogę próbować wpisać swojego kandydata, czuję się traktowany jak analfabeta, lub człowiek, za którego trzeba wszystko decydować. To zniechęca w ogóle do wyborów. Ponadto większość wyborców to bezpartyjni i trzeba nam stworzyć równą możliwość zgłaszania kandydatów, nie czujemy się gorszymi obywatelami ${ }^{26}$.

W podobnym tonie, ale znacznie ostrzej wypowiedział się Tadeusz Adwent z Jeleniej Góry.

Nowa ordynacja wyborcza - pisał - nie zawiera niczego nowego, co miałoby jakiekolwiek znaczenie polityczne. Odpowiada ona treści konstytucji o kierowniczej roli partii w państwie zastrzegającej wszelkie prawa polityczne dla Partyjnego Centrum i uznanych przez nią sojuszników. Reszta społeczeństwa została całkowicie wywłaszczona z praw politycznych. Wyniki wyborów zostaną jak zawsze ustalone o wiele wcześniej przed aktem głosowania. Dla nas, dla bezpartyjnych, a także dla szeregowych członków partii głosowanie jest tylko ceremoniałem składania hołdu

oddawane „bez skreśleń” były uznawane za nieważne. Opowiadali się także przeciwko „dopasowywaniu wyborów do listy głosujących”. „Jeden z nas piszących - czytamy dalej w omawianym liście - był dwukrotnie członkiem komisji, która po odfajkowaniu biorących udział w głosowaniu stwierdziła, że brak było 250 kart do głosowania w kopertach. Przy czystych kartach do głosowania - wzięto owych 250 kart i dodano do liczby pierwszego kandydata, zwiększając sztucznie liczbę głosów. Prawda jest taka, że duża część wyborców chowa do kieszeni karty wyborcze, a czyste koperty bez kart - wrzuca do urny. Owszem była głosować, ale nie chciała popierać kandydatów i zabrała karty do swoich domów. Praktyka ta jest tak powszechna, że społeczeństwo nie wierzy liczbom, podawanym przez PKW o liczbie i oddanych głosach na kandydatów”. APRP, KRP, „Opinie indywidualne dot. «Założeń do projektu ustawy Ordynacja wyborcza do Sejmu PRL», 1985 r., teczka 3”, List Ludwika Wasowskiego, Michała Budziana, Hieronima Kukty, Jacka Rudzińskiego, Edmunda Cholewy, Wiktora Rycyka, Wacława Kotowskiego i Tadeusza Szurzyńskiego do Kancelarii Rady Państwa, Wrocław, 12 II 1985 r., k. nlb.

${ }^{26}$ Ibidem, List Marka Łukaszewskiego do Kancelarii Rady Państwa, Wrocław, 14 III 1985 r., k. nlb. 
na rzecz partii i jej polityki. Złożenie tego hołdu może uchronić nas od szeroko rozumianych represji, ale o niczym nie decyduje i nie może decydować ${ }^{27}$.

Piotr Frendowicz z Torunia wyraził opinię, że Polacy chca faktycznie wybierać, nie zaś, jak przez minionych 40 lat, głosować. Dodał przy tym, że jeśli wybory miałyby odbyć się po raz kolejny na tych samych zasadach, szkoda w ogóle urządzać „ten cały cyrk wyborczy” i marnować trudno dostępne na rynku koperty ${ }^{28}$. „O rozsądek i gospodarność” apelował do władz inny, anonimowy nadawca, który proponował całkowitą rezygnację z wyborów, w których prawdziwość „, i tak nikt nie wierzy”, aby zaoszczędzić pieniądze ${ }^{29}$. Jeszcze dalej poszedł nadawca, podpisany jako „robotnik Huty im. Lenina”, który stwierdził, że nie tylko wybory, ale i w ogóle „fasadowy Sejm” nie jest do niczego potrzebny. Oburzał się także, iż projekt ordynacji stanowi dowód na to, że władze „nadal uważają naród za ciemną masę”. „Bojkot wyborów jest nieunikniony, chyba że "wybory» znów zostaną sfałszowane, co niewątpliwie nastapić musi” ${ }^{30}$ - przewidywał.

Pragnę - głosił natomiast inny anonim, wysłany z Gliwic - aby wybory do Sejmu były naprawdę demokratyczne. Szczególnie należy wykluczyć niedociagnięcia i nieprzestrzeganie ordynacji wyborczej, jakie miały miejsce w wyborach do Rad Komunalnych [chodzi o wybory do rad narodowych z 1984 r. - M.S.], [takie] jak: zastraszanie wyborców, oddawanie głosów za nieobecnych w wyborach itp. Jest ogólnie znane, że miało to miejsce w znacznych przypadkach ${ }^{31}$.

Nadawca listu proponował w związku z tym m.in., aby zakazać, jako formy zastraszania wyborców, wizyt agitatorów w mieszkaniach prywatnych oraz zobowiązać wszystkich głosujących w lokalach wyborczych do korzystania z zasłon ${ }^{32}$.

Treść założeń ogłoszonych przez władze do konsultacji ostro skrytykował W. Mizera (imię nieznane) z Zawiercia.

Nie wiem - czytamy w jego liście do Kancelarii Rady Państwa - kto pracował nad założeniami ordynacji, nie wiem, kto napędzał kampanię prasową po ogłoszeniu założeń do ordynacji w tonie „następny krok na drodze demokratyzacji i znaczący

${ }^{27}$ APRP, KRP, „Opinie indywidualne dot. «Założeń do projektu ustawy Ordynacja wyborcza do Sejmu PRL», 1985 r., teczka 1", List Tadeusza Adwenta do Rady Państwa, Jelenia Góra, 9 I 1985 r., k. nlb.

${ }^{28}$ Ibidem, List Piotra Frendowicza z Torunia do Kancelarii Rady Państwa, Toruń, 18 II 1985 r., k. nlb.

${ }^{29}$ Ibidem, List podpisany nieczytelnie do Rady Państwa PRL, b.m. i d. [data wpływu: 16 I 1985 r.], k. nlb.

${ }^{30}$ Ibidem, List podpisany „Robotnik Huty im. Lenina” do Kancelarii Rady Państwa, Nowa Huta, 13 I 1985 r., k. nlb.

${ }^{31}$ Ibidem, List podpisany „Wyborca z Gliwic” do Kancelarii Rady Państwa, b.d., k. nlb.

32 Ibidem. 
etap w demokratyczności wyborów”. Wiem natomiast, że ani jedna zmiana, ani jeden wariant nie dotyczy istoty problemu. Toteż opinie, że konsultacje obywatelskie spowodują wybór wariantu, czy Sejm ma liczyć 460 czy 500 posłów, bierne prawo wyborcze od 18 czy 21 lat, to zwykły wybieg, a nawet oszustwo. Bo wiadomo, że istota prawdziwych i demokratycznych wyborów tkwi: 1) w obowiązku, a nie prawie tajności wyboru (czyli praktycznie obowiązku korzystania z kabiny); 2) alfabetycznym ułożeniu nazwisk na liście kandydatów na posłów; 3) możliwości zgłaszania kandydatów przez grupy niezrzeszonych obywateli. Twierdzę, że spełnienie chociaż części z ww. postulatów daje gwarancję zmiany nastawienia do wyborów do Sejmu. [...] Dlaczego władzom - również w założeniach do ordynacji do Sejmu - tak bardzo zależy na prawie umieszczania kandydatów w przez siebie inspirowanej kolejności? Czyżby to pewność, że obywatele nie będą dokonywać skreśleń? ${ }^{33}$

Krytyczne opinie o systemie wyborczym PRL wychodziły także spod pióra osób, które deklarowały się jako zwolennicy socjalizmu w Polsce. W taki sposób określił się Władysław Skobelski z Gdańska, jednocześnie dodając, że walczył „o utrwalanie władzy ludowej”, czuje się uprawniony do zabierania głosu i chciałby zostać wysłuchany. Swoje uwagi sformułował w sposób wyważony, w liście skierowanym do kilku instytucji pisząc m.in., że

obowiązek skreślania kandydatów na listach wyborczych daje możliwość rzeczywistego wyboru. Wyborca - kontynuował - musi wybrać spośród zaproponowanych mu kandydatów swojego posła, któremu zaufa. Prawda, że wybór będzie ograniczony, ale zawsze będzie wyborem jednego z dwóch. Wrzucanie kartki nieskreślonej nie jest aktem wyboru, lecz jest najczęściej aktem rezygnacji. Prawie wszyscy moi znajomi twierdza, że nawet jeżeli będą skreślać, to i tak nie będzie to miało wpływu na wynik głosowania, ponieważ ogłoszone oficjalnie wyniki głosowania nie będą prawdziwe. Jeżeli nie przekonamy wyborców do tego, że nasze wybory do Sejmu sa naprawdę demokratyczne, a wyniki głosowania będą prawdziwe, to wyborcy pozostaną nadal zrezygnowani i obojętni na wszystko, co się dzieje w państwie, nikt ich nie zdoła zachęcić do wydajnej pracy, do poparcia programu wyborczego. [...] Należy pamiętać o zasadniczej prawdzie, że nawet najlepsi ludzie wprowadzeni do Sejmu w wyniku niedemokratycznych wyborów nie wyprowadzą kraju z kryzysu, ponieważ nie zdobędą zaufania społeczeństwa, natomiast ci sami ludzie wybrani w wyborach demokratycznych moga zdziałać cuda - zachęcić społeczeństwo do solidnej, wydajnej pracy, która przyniesie dobrobyt ${ }^{34}$.

O możliwym podniesieniu rangi Sejmu dzięki demokratyzacji praktyk wyborczych pisał też Robert Lidke z Warszawy.

Uważam że praktykowane przez niektórych wyborców jawne głosowanie - czytamy w jego liście - jest niedopuszczalną formą nacisku psychicznego i moralnego na innych wyborców, aby też głosowali jawnie. W ten sposób nasza ordynacja wyborcza

${ }^{33}$ Ibidem, List W. Mizery z Zawiercia do Kancelarii Rady Państwa, b.d., k. nlb.

${ }^{34}$ Ibidem, List Władysława Skobelskiego do Rady Państwa, Komisji Prac Ustawodawczych Sejmu, Rady Krajowej PRON, Rady Wojewódzkiej PRON w Gdańsku, Redakcji tygodnika PRON „Odrodzenie”, Gdańsk, 22 I 1985 r., k. nlb. 
staje się ordynacją trzy, a nie czteroprzymiotnikowa. Jestem przekonany, iż obowiązek tajnego głosowania, ze skreśleniami na karcie z kandydatami przedstawionymi w kolejności alfabetycznej podniesie rangę Sejmu, jak i samych wyborów ${ }^{35}$.

Ciekawe komentarze wychodziły niejednokrotnie spod pióra szeregowych członków PZPR i działaczy terenowych. Taką osobą był np. Zygmunt Melasa z Radzymina, który proponował rezygnację z dzielenia miejsc na listach na mandatowe i niemandatowe oraz praktyki głosowania „bez skreśleń”, odbierającej wyborcom możliwość faktycznego wyboru. Skarżył się przy tym, że jako członek partii musi „niejednokrotnie słuchać uszczypliwych uwag na temat formalnej demokracji i braku wpływu świadomego wyborcy na wynik wyborów" ${ }^{36}$. Z kolei Stanisław Łodyga, radny Gminnej Rady Narodowej z Mińska Mazowieckiego, odnosząc się do propozycji wydłużenia głosowania do dwóch dni, stwierdził:

\begin{abstract}
Wnioskuję, żeby przy głosowaniu przyjąć wariant I w godz. 6-22. Jesteśmy już przyzwyczajeni, że wybory trwają jeden dzień, będą mniejsze koszty i mniej czasu na kombinacje, które wyczerpują znamiona przestępstwa z art. 189 par. 1 kk. Tak, kombinacje, gdyż jako działacz gminny mam w tym zakresie pewne doświadczenia. Wyborcy zdaja sobie sprawę, że akt głosowania nie zmieni stanu rzeczy i lekceważą ten obowiązek. Szczególnie jaskrawo ujawniło się to przy ostatnich wyborach [chodzi o wybory do rad narodowych z 1984 r. - M.S.]. Żeby przekroczyć granicę 50 proc. frekwencji, działacze gminy i pracownicy KG staja dosłownie na głowie, a na dodatek [dochodzi] ponaglanie $\mathrm{z}$ województwa i stąd rodzi się przestępstwo fałszowania wyborów - głównie fikcyjne zwiększanie liczby głosujących. Nie będę wchodził w szczegóły, jak to było, ale sądzę, że jeśli „stary” sejm uchwali „Ustawę Ordynacja wyborcza do Sejmu PRL” z lista, gdzie będzie po dwóch kandydatów w obrębie każdego mandatu, ciężko nam będzie tu na dole podołać obowiązkom zorganizowania głosowania zgodnie $\mathrm{z}$ prawem $^{37}$.
\end{abstract}

Swoimi uwagami z szefem KRP postanowił podzielić się także Stefan Jędrychowski, przez wiele lat członek najwyższego kierownictwa partyjno-państwowego (m.in. kierownik Resortu Informacji i Propagandy PKWN, poseł Krajowej Rady Narodowej, Sejmu Ustawodawczego i Sejmu PRL I-V kadencji, w latach 1951-1956 wicepremier, w okresie rządów Władysława Gomułki członek Biura Politycznego KC PZPR, w latach siedemdziesiątych minister spraw zagranicznych i minister finansów, następnie ambasador PRL na Węgrzech $\left.{ }^{38}\right)$, wówczas już na politycznej emeryturze. Na wstępie stwierdził, że ogłoszone warianty zmian dotyczą spraw „mniej ważnych”. Proponował dalej, aby czyste głosy były zaliczane na konto wszystkich kandydatów. Choć

${ }^{35}$ Ibidem, List Roberta Lidke do Kancelarii RP, Warszawa, 10 I 1985 r., k. nlb.

${ }^{36}$ Ibidem, List Zygmunta Melasy do Kancelarii Rady Państwa, Radzymin, 9 I 1985 r., k. nlb.

${ }^{37}$ Ibidem, List Stanisława Łodygi z Mińska Mazowieckiego do Kancelarii Rady Państwa, 9 I 1985 r., k. nlb.

38 T. Mołdawa, Ludzie władzy 1944-1991. Władze państwowe i polityczne Polski wedtug stanu na dzień 28 II 1991, Warszawa 1991, s. 365-366. 
sam wielokrotnie kandydował w wyborach, w których praktykowano głosowanie „bez skreśleń”, wyraził opinię, że lepszym od skreślania jest zaznaczanie, które osoby na liście się popiera - wówczas mamy do czynienia z pozytywnym wyborem. Chciał także zniesienia podziału na miejsca mandatowe i niemandatowe poprzez alfabetyczne szeregowanie osób ubiegających się o mandaty na listach wyborczych ${ }^{39}$.

Do odosobnionych, wśród opinii nadesłanych władzom przez indywidualnych nadawców, należało pismo przesłane do KRP przez prof. Tadeusza Wilocha z Instytutu Badań Pedagogicznych w Warszawie, który „z dużą satysfakcją" przeczytał projekt nowej ordynacji i ocenił, że jest on „naprawdę demokratyczny, a wysunięcie do dyskusji propozycji wariantowych jeszcze bardziej uwydatnia demokratyczność założeń do projektu ustawy"40.

W listach nadesłanych przez wyborców do władz podczas konsultacji najczęściej pojawiały się postulaty: wprowadzenia obowiązkowej tajności głosowania, zamieszczenia kandydatów w obrębie listy w kolejności alfabetycznej i zniesienia podziału na miejsca mandatowe i niemandatowe oraz uznawania głosów oddanych „bez skreśleń” za nieważne. Z postulatami takimi wystapił m.in. anonimowy mieszkaniec Mikołowa. Tłumaczył przy tym, że „listy z umieszczonymi 2 kandydatami w obrębie każdego mandatu i to jeszcze w kolejności dowolnej - to jaskrawy przejaw «typowania» osób, które maja być wybrane". Jako członek komisji wyborczej w minionych wyborach do rad narodowych na podstawie „wnikliwej obserwacji” stwierdził bowiem, „iż teoretyczna możliwość skreślenia pierwszej osoby w obrębie mandatu jest utopia, gdyż «wyborcy» najczęściej wrzucali kartki do urny, nawet ich nie czytając" ${ }^{41}$. Adam Sikora skonstatował z kolei, że od 40 lat możliwość zgłaszania kandydatów maja tylko partia i tzw. stronnictwa sojusznicze, odmawia się natomiast takiego prawa obywatelom wierzacym i bezpartyjnym, którzy stanowią 80\% społeczeństwa. Postulował w związku z tym, aby sprawą zgłaszania kandydatów wierzących i bezpartyjnych zają się Kościół. Sugerował, by wszystkich kandydatów podzielić na cztery odrębne listy: PZPR, Zjednoczone Stronnictwo Ludowe (ZSL), Stronnictwo Demokratyczne (SD) i niezależna, przygotowaną pod egidą Kościoła. Dodatkowo żądał wznowienia działalności NSZZ „Solidarnośćc"

${ }^{39}$ APRP, KRP, „Opinie indywidualne dot. «Założeń do projektu ustawy Ordynacja wyborcza do Sejmu PRL», 1985 r., teczka 3”, List Stefana Jędrychowskiego do Szefa Kancelarii Rady Państwa Jerzego Breitkopfa, Warszawa, 9 II 1985 r., k. nlb.

40 APRP, KRP, „Opinie indywidualne dot. «Założeń do projektu ustawy Ordynacja wyborcza do Sejmu PRL», 1985 r., teczka 1", List prof. dr. hab. Tadeusza Wilocha z Instytutu Badań Pedagogicznych w Warszawie do Kancelarii Rady Państwa, Warszawa, 7 I 1985 r., k. nlb.

${ }^{41}$ Ibidem, List z podpisem nieczytelnym, bez wpisanego w stopce konkretnego adresata, Mikołów, 8 I 1985 r., k. nlb.

${ }^{42}$ Ibidem, List Adama Sikory do Przewodniczącego Rady Państwa PRL, Wrocław, 10 I 1985 r., k. nlb. 
„Zawiedzeni, manipulowani, oszukiwani” - tak zdaniem M. Wieleckiego z Gdańska mieli czuć się wyborcy, uczestnicząc w niedemokratycznych i niesprawiedliwych głosowaniach. Wielecki wskazywał na oczywisty fakt, iż tylko wybory zapewniające rzeczywistą rywalizację różnych partii politycznych, wystawiających odrębne listy kandydatów, są prawdziwymi wyborami. Upominając się o wprowadzanie „prawdziwej demokracji”, pisał również, iż najbardziej zraża go w peerelowskich wyborach to, że głosy „bez skreśleń” przyznawane sa kandydatom z miejsc mandatowych. „Jest to - oceniał - oczywisty absurd i jakaś szydercza kazuistyka i łamańce nieuczciwej gry”. Co więcej, jego zdaniem praktyka ta narażała Polskę na bycie „pośmiewiskiem świata”, podczas gdy w istocie Polacy potrafia sami dokonywać wyboru. „Dlaczego - pytał retorycznie - ktoś z komisji ma lepiej wiedzieć i znać «lepszego» kandydata z góry, niejako przed wyborami rozstrzyga[ć] - kto będzie wybrany a kto nie" ${ }^{\prime 3}$.

Wiele ciekawych opinii wpłynęło do KRP także od różnego rodzaju oficjalnych organizacji, w tym terenowych instancji PZPR. Były one bardziej wyważone niż większość listów przesłanych przez prywatnych nadawców, niemniej jednak także w nich nie brakowało krytycznej analizy. W bardzo wielu przewijał się postulat rezygnacji z dzielenia miejsc na listach wyborczych na mandatowe i niemandatowe oraz wprowadzenia obowiązku wykreślania z kart przez wyborców niepopieranych kandydatów w tajnym głosowaniu. W takim wypadku głosy oddane „bez skreśleń” miałyby zostać uznane za nieważne lub odnoszące się do wszystkich kandydatów. Z tego rodzaju wnioskami wystapiły m.in.: podstawowe organizacje partyjne PZPR przy Instytucie Sadownictwa i Kwiaciarstwa w Skierniewicach ${ }^{44}$ oraz przy Szkole Podstawowej w Osjakowie ${ }^{45}$, organizacja Związku Socjalistycznej Młodzieży Polskiej przy Hydrobudowie w Poznaniu ${ }^{46}$, koło SD w Wysokiem Mazowieckiem ${ }^{47}$, Gminny Komitet ZSL w Milejowie ${ }^{48}$, ogniwa PRON przy Przedsiębiorstwie Budownictwa Komunalnego w Świdnicy ${ }^{49}$ i Zakładach

${ }^{43}$ Ibidem, List M. Wieleckiego do Kancelarii Rady Państwa, Biura Rady Krajowej PRON i redakcji tygodnika „Odrodzenie”, Gdańsk, b.d. [data wpływu: 18 I 1985 r.], k. nlb.

${ }^{44}$ APRP, KRP, „Opinie "zbiorowości» dot. «Założeń do projektu ustawy Ordynacja wyborcza do Sejmu PRL», 1985 r., teczka 2", Wnioski z dyskusji nad projektem ordynacji wyborczej do Sejmu PRL przesłane do Kancelarii Rady Państwa z Podstawowej Organizacji Partyjnej PZPR przy Instytucie Sadownictwa i Kwiaciarstwa w Skierniewicach, 22 II 1985 r., k. nlb.

${ }^{45}$ Ibidem, List z Podstawowej Organizacji Partyjnej PZPR przy Szkole Podstawowej w Osjakowie, podpisany przez I sekretarza POP Andrzeja Ziętka, 15 I 1985 r., k. nlb.

${ }^{46}$ Ibidem, Stanowisko organizacji młodzieżowej ZSMP przy „Hydrobudowie - Poznań” PRIB w Poznaniu w sprawie założeń do projektu ustawy Ordynacja wyborcza do Sejmu PRL, 12 II 1985 r., k. nlb.

${ }^{47}$ Ibidem, Pismo Koła Terenowego SD w Wysokiem Mazowieckiem do Kancelarii Rady Państwa, 15 II 1985 r., k. nlb.

${ }^{48}$ Ibidem, Pismo Gminnego Komitetu ZSL w Milejowie do Kancelarii Rady Państwa, 11 III 1985 r., k. nlb.

${ }^{49}$ Ibidem, Pismo Patriotycznego Ruchu Odrodzenia Narodowego przy Przedsiębiorstwie Budownictwa Komunalnego w Świdnicy do Kancelarii Rady Państwa, b.d., k. nlb. 
Przemysłu Metalowego „Cegielski” w Poznaniu ${ }^{50}$ oraz Zarząd Okręgu Związku Nauczycielstwa Polskiego (ZO ZNP) w Koninie ${ }^{51}$. Nawiazujac do praktyki głosowania „w zastępstwie”, ZO ZNP w Białej Podlaskiej stwierdził z kolei, że „każdy z wyborców powinien własnoręcznym podpisem potwierdzić swój udział w wyborach. Będzie to najbardziej demokratyczne i nie pozwalające na jakiekolwiek machinacje" ${ }^{52}$.

Obszerne, ciekawe uwagi przesłali do KRP pracownicy Instytutu Państwa i Prawa Polskiej Akademii Nauk.

\begin{abstract}
W pełni rozumiemy i akceptujemy - deklarowali na wstępie - konieczność zabezpieczenia trwałości władzy ludowej w Polsce. Rozumiemy, że nie może ona być przedmiotem „wolnej gry sił” w wyborach, czego konsekwencją jest niedopuszczenie opozycji antysocjalistycznej do wystawiania swych kandydatów w wyborach oraz fakt, że kandydatów wysuwają tylko siły polityczne akceptujące socjalizm i występujące w wyborach, z racji sojuszu politycznego, z jedną wspólną listą. Uznając nadrzędność tej politycznej konieczności uważamy jednak, że rozwój demokracji socjalistycznej wymaga rozszerzania możliwości dokonywania przez obywateli uczestniczaccych w wyborach wyboru między kandydatami reprezentujaccymi ten sam program polityczny ${ }^{53}$.
\end{abstract}

Dalej w przesłanym liście znalazło się stwierdzenie, że Polacy masowo żądają demokratyzacji systemu politycznego, oraz omówienie różnych podejść do funkcji wyborów jako czynnika stabilizacji władzy. Zdaniem autorów uwag władze PRL w projekcie przedstawionym do konsultacji poszły droga utrzymania społecznej inercji, proponowały „system umacniajaccy i pogłębiający bierność zarówno obywateli niezobowiązanych do zajęcia jakiegokolwiek stanowiska w wyborach, jak i aparatu politycznego organizujacego wybory" ${ }^{54}$. $\mathrm{W}$ podsumowaniu przedstawionych rozważań ich autorzy napisali:

W sumie Założenia proponują wprowadzenie następujacych zabezpieczeń socjalistycznego systemu władzy: 1) ograniczenie prawa wysuwania kandydatów do oficjalnych podmiotów systemu politycznego (głównie sygnatariusze PRON), 2) wyeliminowanie prawnie ważnego wpływu wyborców na skład list kandydatów prezentowanych w wyborach, oddanie całości decyzji w tej mierze konwentom wyborczym złożonym z sygnatariuszy PRON, 3) preferencyjny układ kandydatów na kartach do głosowania, 4) uznanie kart bez skreśleń za głosy ważne oddane na kandydatów preferowanych, 5) traktowanie tajności głosowania jako prawa wyborcy, a nie koniecznego elementu procedury wyborczej, 6) instytucja list regionalnych jako odmiany listy państwowej,

${ }^{50}$ Ibidem, Pismo Patriotycznego Ruchu Odrodzenia Narodowego przy Zakładach Przemysłu Metalowego „Cegielski” w Poznaniu do Kancelarii Rady Państwa, 6 III 1985 r., k. nlb.

${ }^{51}$ Ibidem, Uwagi i propozycje do projektu założeń ustawy „Ordynacja wyborcza do Sejmu PRL” przesłane do KRP przez ZO ZNP w Koninie, 4 II 1985 r., k. nlb.

${ }^{52}$ Ibidem, List Zarządu Okręgu Związku Nauczycielstwa Polskiego w Białej Podlaskiej do Kancelarii Rady Państwa, 24 I 1985 r., k. nlb.

${ }^{53}$ Ibidem, Uwagi do Założeń projektu ordynacji wyborczej do Sejmu PRL zgłoszone na zebraniu naukowym Instytutu Państwa i Prawa PAN dn. 30 I 1985 r., Warszawa, 7 II 1985 r., k. nlb.

${ }^{54}$ Ibidem. 
7) karta do głosowania podzielona na poszczególne mandaty. W pełni respektując konieczność wbudowania do prawa wyborczego systemu zabezpieczeń politycznego wyniku wyborów, trzeba jednak zadać pytanie, czy zabezpieczeń tych nie jest zbyt wiele w Założeniach. W pełni skutecznie eliminują możliwość ubiegania się o mandat przez stronników opozycji politycznej instytucje ad 1) i ad 2) (druga nawet z dużą przesada, gdyż posuwa się do wyeliminowania praktycznego wpływu wyborców na skład list kandydatów); zachowanie w organie przedstawicielskim składu politycznego w pełni zgodnego z wcześniejszymi ustaleniami politycznymi zapewnia instytucja ad 7). Reszta zabezpieczeń jest już zatem zbędna i niepotrzebnie ograniczają one swobodę wyborców ${ }^{55}$.

Wydawać by się mogło, że dysponując takimi opiniami, władze PRL zdecydują się na przynajmniej częściowe dostosowanie nowych przepisów do oczekiwań społecznych wysuwanych, jak wspomniano, także przez reżimowe organizacje, w tym członków samej PZPR. W opracowanej w KRP notatce o wynikach konsultacji projektu ordynacji (na bieżąco informowano o tym sekretarza KC Tadeusza Porębskiego, kierownika Wydziału Organizacyjnego KC Kazimierza Cypryniaka i jego zastępcę Leszka Jaszczewskiego ${ }^{56}$ ) znalazły się jednak jedynie zdawkowe informacje, w niewielkim stopniu oddające stan sytuacji wyłaniający się z analizy przywoływanych wyżej materiałów. Według rzeczonego dokumentu do KRP miało wpłynać blisko 300 listów, w tym ok. 30\% anonimowych. Jego autor/ autorzy doszli do wniosku, że największe zainteresowanie wzbudzały zasady głosowania i ustalania jego wyników. Pośród odrzuconych propozycji wskazano obniżenie cenzusu wieku biernego prawa wyborczego do 18 lat oraz dwudniowe głosowanie. Odnotowano, że „stosunkowo wiele” postulatów dotyczyło wprowadzenia obligatoryjnej tajności głosowania, a 1/3 - zamieszczania kandydatów na listach wyborczych w kolejności alfabetycznej. W opracowaniu natomiast w ogóle nie wzięto pod uwagę znacznej ilości bardzo krytycznych opinii, które podważały de facto fundamenty hegemonii $\mathrm{PZPR}^{57}$. W podsumowaniu stwierdzono, że „wyniki konsultacji - aczkolwiek nie w pełni reprezentatywne - świadcza o postępującej normalizacji nastrojów społecznych, ale jednocześnie o pewnej bierności postaw w stosunku do przedstawionych propozycji"58.

Zmiany w przepisach prawa wyborczego, przeprowadzone przed wyborami do Sejmu PRL IX kadencji, nie wpłynęły, bo i w uchwalonym kształcie ${ }^{59}$

55 Ibidem.

${ }^{56}$ APRP, KRP, „Informacje o wynikach społecznej konsultacji «Założeń do projektu ustawy Ordynacja wyborcza do Sejmu PRL», 1985 r.”, Pismo przewodnie do informacji nr 1 o uwagach, opiniach i wnioskach do założeń projektu Ordynacji wyborczej do Sejmu PRL nadesłanych [do Kancelarii Rady Państwa] do dnia 23 I 1985 r., Warszawa, 24 I 1985 r., k. nlb.

${ }^{57}$ Ibidem, Informacja o wynikach społecznej konsultacji „Założeń do projektu Ordynacji wyborczej do Sejmu PRL”, opracowana na podstawie opinii i uwag zgłoszonych do Kancelarii Rady Państwa, Warszawa, 27 III 1985 r., k. nlb.

58 Ibidem.

${ }^{59}$ Zob. Ustawa z dnia 29 maja 1985 r. Ordynacja wyborcza do Sejmu Polskiej Rzeczypospolitej Ludowej, DzU 1985, nr 26, poz. 112. 
wpłynąć nie mogły, na rzeczywistą demokratyzację systemu. Choć o każdy mandat ubiegało się dwóch pretendentów, zachowano preferencyjny układ kandydatów na listach, z podziałem na miejsca mandatowe i niemandatowe. W Sejmie PRL IX kadencji znaleźli się wszyscy, którzy kandydowali z miejsc mandatowych. Podziału politycznego mandatów w izbie dokonano jeszcze przed uchwaleniem nowej ordynacji, co nastapiło 29 V 1985 r. Tymczasem o jeden dzień wcześniej datowany jest dokument, przygotowany w Wydziale Organizacyjnym KC PZPR, zakładajacy obsadzenie 245 foteli poselskich reprezentantami PZPR, 106 - przedstawicielami ZSL, 35 - SD, a 74 - bezpartyjnymi ${ }^{60}$. Obsada polityczna ław sejmowych po wyborach, które odbyły się dopiero 13 X 1985 r., w 100\% odpowiadała tym założeniom ${ }^{61}$.

Zaprezentowane w niniejszym szkicu listy stanowią tylko fragment korespondencji, która wpłynęła do KRP w związku z tzw. konsultacjami społecznymi projektu nowej ordynacji wyborczej do Sejmu PRL w 1985 r. Nie sposób na jej podstawie twardo oszacować, jaki odsetek Polaków popierał praktyki wyborcze stosowane przez PZPR, jednak wydaje się, że przekonanie o fasadowości wyborów w PRL było powszechne, włączając członków reżimowych organizacji, na czele z sama partia. Pewien wpływ na ten stan rzeczy miała działalność opozycji antykomunistycznej, która w licznych publikacjach drugoobiegowych obnażała rzeczywiste mechanizmy niedemokratycznej władzy. Majac na uwadze wzmiankowane w szkicu opinie na temat głosowań z okresu budowy w Polsce ustroju komunistycznego, można też przypuszczać, że część polskiego społeczeństwa nigdy nie dała się przekonać, że wybory urządzane przez PZPR są czymś więcej niż propagandowymi spektaklami. Jeśli przez kolejne dziesięciolecia Polacy w nich uczestniczyli, to niekoniecznie z wiara, że faktycznie wybieraja swoich przedstawicieli.

\section{Streszczenie}

W całym okresie rządów komunistycznych w Polsce nie przeprowadzono nigdy wolnych wyborów do organów przedstawicielskich. Komuniści sfałszowali już pierwsze dwa powojenne głosowania (tzw. referendum ludowe w 1946 i wybory do Sejmu Ustawodawczego w 1947 r.), co utorowało im drogę do pełnej władzy. Ówczesne fałszerstwa były szczególnie rażące, z czego Polacy zdawali sobie sprawę. W kolejnych dziesięcioleciach liderzy PZPR przy organizacji wyborów bardziej dbali już o zachowanie demokratycznych pozorów, a propaganda miała przekonać społeczeństwo, że socjalistyczne wybory stanowią kwintesencję demokracji. Jeśli ktoś był innego zdania, nie mógł swoich poglądów prezentować oficjalnie bez narażania się na represje. Okazją do wyrażenia prawdziwej opinii o praktykach wyborczych PRL dla wielu ludzi stały się tzw. konsultacje społeczne projektu nowej ordynacji wyborczej do Sejmu PRL, ogłoszone przez władze na początku 1985 r. Podczas konsultacji do Kancelarii Rady Państwa

\footnotetext{
${ }^{60}$ AAN, KC PZPR, V/266, Informacja o zasadach kształtowania składu politycznego i społeczno-zawodowego Sejmu PRL, Warszawa, 28 V 1985 r., k. 21.

${ }_{61}$ Zob. Archiwum danych o postach, http://orka.sejm.gov.pl/ArchAll2.nsf (dostęp: 21 V 2018).
} 
i innych instytucji wpłynęła spora liczba listów od osób prywatnych i różnych organizacji, w których dominowały głosy krytyczne. Powszechnie krytykowano praktyki stosowane $\mathrm{w}$ dotychczasowych peerelowskich głosowaniach, stanowiące podstawowe instrumenty kontroli PZPR nad przebiegiem wyborów, w tym przede wszystkim blokowanie zgłaszania niezależnych kandydatów, narzucanie jawnego głosowania „bez skreśleń” i przyznawanie kandydatom zamieszczonym na tzw. miejscach mandatowych oddanych w ten sposób głosów. Domagano się demokratyzacji, wprowadzenia obowiązkowej tajności wyborów, zamieszczenia kandydatów w obrębie listy w kolejności alfabetycznej i zniesienia podziału na miejsca mandatowe i niemandatowe oraz uznawania głosów oddanych „bez skreśleń” za nieważne. Mimo takich opinii władze nie zdecydowały się na chociażby minimalna, rzeczywista demokratyzację. Zmiany w przepisach prawa wyborczego, wprowadzone w 1985 r., miały iluzoryczny charakter, a skład polityczny Sejmu określono jeszcze przed ich formalnych uchwaleniem. Autor artykułu stawia natomiast tezę, iż przez kolejne dziesięciolecia trwania rządów PPR/ PZPR Polacy nawet jeśli brali udział w powszechnych głosowaniach, zdawali sobie sprawę $\mathrm{z}$ ich fasadowego charakteru.

\section{Social Perception of Elections in the Polish People's Republic in the Light of Letters sent to the Authorities during a Consultation of the Draft of a New Electoral Law to the Sejm in 1985}

Throughout the whole communist period in Poland, there were no free elections to the representative organs of the state. Communists fixed already the two first post-war elections (the so-called People's Referendum of 1946 and the 1947 parliamentary election to the Legislative Sejm), which paved them the way to acquire full power. Those falsifications were especially gross, and the people were aware of them. In the successive decades, the party leaders were more concerned to keep up democratic appearances, and the official propaganda was to convince the people that socialist elections were the gist of democracy. People holding a contrary opinion could not voice it openly without the risk of being victimised. An occasion to express their true opinions about the electoral practices of the Polish people's Republic were, for many Polish citizens, the so-called social consultations of the draft of a new electoral law to the Sejm, launched by the regime in the early 1985 . During the consultations, a large number of letters were sent to the Chancellery of the State Council and other institutions both by private individuals and various organisations. The letters were dominated by critical opinions about the practices during elections which were the basic tools of control for the party over the course of elections, mainly the blocking of independent candidates, imposing of the open vote without crossing out, and giving these voices to the candidates on the so-called mandatory positions. The letters' authors demanded democratisation, an introduction of obligatory secret vote, an alphabetic order of candidates within a list, abolishment of the mandatory and non-mandatory positions, and counting voices without crossing-outs as invalid. Despite such opinions, the regime did not decide to democratise the country even in a minimal degree. Changes in the new electoral law introduced in 1985 were of illusionistic character, and the political composition of the Sejm had been established before they officially passed. The author of the article argues that in the successive decades of the rule of the Polish Workers' Party/Polish United Workers' Party, even if they had voted in universal elections, the Polish people were aware of their window-dressing nature. 


\section{Bibliografia}

Bereszyński Z., Wybory w latach 1972-1989 oraz referendum społeczne $w 1987$ r. na Ślasku Opolskim. Dziatania aparatu wtadzy i środowisk opozycyjnych, akcje antywyborcze oraz spontaniczne przejawy postaw opozycyjnych wśród mieszkańców regionu, w: Wybory $i$ referenda $w$ PRL, red. S. Ligarski, M. Siedziako, Szczecin 2014, s. 263-332.

Brzechczyn K., Wybory do Sejmu i rad narodowych w programie i myśli politycznej NSZZ „Solidarnośc” $w$ latach 1980-1981, w: Wybory i referenda $w$ PRL, red. S. Ligarski, M. Siedziako, Szczecin 2014, s. 685-704.

Budzyńska C., Strzępy rodzinnej sagi, Warszawa 1997.

Danilecki T., Formy oporu społecznego zwiazanego $z$ wyborami powszechnymi $w$ Polsce $w$ okresie „małej stabilizacji”- zarys problematyki, „Pamięć i Sprawiedliwość” 2012, nr 1 (19).

Dąbrowska M., Dzienniki. 1914-1965, t. I-XIII, oprac. W. Starska-Żakowska, Warszawa 2009.

Dworaczek K., Opozycja wobec wyborów do Sejmu PRL w 1980 r., w: Wybory i referenda w PRL, red. S. Ligarski, M. Siedziako, Szczecin 2014, s. 665-683.

Eisler J., Siedmiu wspaniatych. Poczet pierwszych sekretarzy KC PZPR, Warszawa 2014.

Friszke A., Czas KOR-u. Jacek Kuroń a geneza Solidarności, Kraków 2011.

Janowski K.B., Źródta i przebieg zmiany politycznej w Polsce 1980-1989. Studium historyczno-politologiczne, Toruń 2004.

Kisielewski S., Dzienniki, Warszawa 2001.

Kowal P., Koniec systemu wtadzy. Polityka ekipy gen. Wojciecha Jaruzelskiego $w$ latach 1986-1989, Warszawa 2012.

Ligarski S., Społeczeństwo polskie wobec wyborów do sejmu w 1976 i 1980 roku, w: Opozycja demokratyczna $w$ PRL $w$ latach 1976-1981, red. W. Polak, J. Kufel, P. Ruchlewski, Gdańsk 2012, s. 328-348.

Lipski J.J., Dzienniki 1954-1957, przedm. A. Friszke, oprac. Ł. Garbal, Warszawa 2010.

Mażewski L., Posttotalitarny autorytaryzm PRL 1956-1989. Analiza ustrojowopolityczna, Warszawa-Biała Podlaska 2011.

Mołdawa T., Ludzie władzy 1944-1991. Władze państwowe i polityczne Polski wedtug stanu na dzień 28 II 1991, Warszawa 1991.

O wolne wybory w PRL. Zbiór dokumentów (1980-1989), wstęp A. Pleśniar, Wrocław 1989.

Olejniczak J., Wybory do Sejmu i rad narodowych w okresie rzadów Wtadystawa Gomutki, w: Wybory i referenda w PRL, red. S. Ligarski, M. Siedziako, Szczecin 2014, s. 151-167.

Paczkowski A., Pułapki „Dzienników” Rakowskiego, „Polityka” 2013, nr 15.

Polak W., Bojkot wyborów do sejmu i rad narodowych $w$ regionie toruńskim $w$ latach 1984 1988, w: O Polskę wolna! O Polskę solidarna! NSZZ Solidarność w latach 1980-1989, red. W. Polak i in., Gdańsk 2011, s. 193-207.

Polak W., Rysunki satyryczne jako narzędzie propagandy antywyborczej $w$ latach osiemdziesiatych, w: Wybory i referenda w PRL, red. S. Ligarski, M. Siedziako, Szczecin 2014, s. $721-736$.

Przeperski M., PRON - nowy pas transmisyjny. Przyczynek do nacjonalistycznej próby legitymizacji ustroju w poczatku lat 80., „Studia Migracyjne - Przegląd Polonijny” 2010, z. 1 (135).

Raciborski J., Wiatr J.J., Wybory w PRL. Doświadczenia $i$ wnioski, Warszawa 1987.

Rakowski M.F., Dzienniki polityczne 1958-1990, [t. I-X], Warszawa 1998-2005.

Rupnik J., The Military and „Normalisation” in Poland, w: Eastern Europe. Political Crisis and Legitimation, ed. P.G. Lewis, London-Sydney 1984, s. 154-175.

Siedziako M., Bez wyboru. Gtosowania do Sejmu PRL (1952-1989), Warszawa 2018.

Siedziako M., Manipulacje i fatszerstwa wyborcze $w$ wyborach do Sejmu PRL (1952-1985), „Pamięć i Sprawiedliwość” 2016, nr 1 (27). 
Siedziako M., Partia wybiera, społeczeństwo głosuje. Jak wytaniano Sejm PRL (1952-1985), w: Elity komunistyczne w Polsce, red. M. Szumiło, M. Żukowski, Warszawa-Lublin 2015, s. $192-223$.

Skoczylas M., Wybory do Sejmu Ustawodawczego z 19 stycznia 1947 r. w świetle skarg ludności, Warszawa 2003.

Świda-Ziemba H., Człowiek wewnętrznie zniewolony. Problemy psychosocjologiczne minionej formacji, Warszawa 1998.

Torańska T., Oni, Warszawa 1989.

Waligóra G., Bojkot wyborów w latach 1984-1985, w: Wybory i referenda w PRL, red. S. Ligarski, M. Siedziako, Szczecin 2014, s. 705-719.

Waligóra G., Ruch Obrony Praw Człowieka i Obywatela 1977-1981, Warszawa 2006.

Wąsowicz SDB J., „Nie pójdziemy na wybory!” Akcje bojkotu wyborów organizowane przez młodzieżowe organizacje niezależne $w$ Gdańsku $w$ latach 1984-1988, w: Wybory i referenda $w$ PRL, red. S. Ligarski, M. Siedziako, Szczecin 2014, s. 737-762.

Wolsza T., Zaćmiński A., Ludzie listy pisza... Referendum i wybory do Sejmu w korespondencji Polaków (1946-1952), Bydgoszcz 2013.

Wyszyński S., Pro Memoria, t. I: 1948-1952, red. P. Skibiński, Warszawa 2017.

Zabłocki J., Dzienniki 1956-1986, t. I-III, wstęp J. Żaryn, oprac. M. Barcikowski i in., Warszawa 2008-2013.

Zaćmiński A., „Identyfikacja wroga” w wyborach do Sejmu PRL z 26 października 1952 r. - metodologia pracy Ministerstwa Bezpieczeństwa Publicznego, w: Wybory i referenda $w$ PRL, red. S. Ligarski, M. Siedziako, Szczecin 2014, s. 123-147.

Zaremba M., Klimat emocjonalny $w$ Polsce lat osiemdziesiatych. Studium na podstawie raportów Biura „W”, w: Spoteczeństwo polskie w latach 1980-1989, red. N. Jarska, J. Olaszek, Warszawa 2015, s. 13-34.

Zaremba M., Wielka trwoga. Polska 1944-1947. Ludowa reakcja na kryzys, Kraków 2012.

Zawieyski J., Dzienniki, t. I: Wybór z lat 1955-1959, t. II: Wybór z lat 1960-1969, wybór i oprac. A. Knyt i in., Warszawa 2011-2012.

Biogram: Michał Siedziako - dr nauk społecznych, politolog i historyk, pracownik Oddziałowego Biura Badań Historycznych IPN w Szczecinie oraz Wyższej Szkoły Integracji Europejskiej tamże. Autor kilkudziesięciu publikacji naukowych, współredaktor kilku prac zbiorowych. Zainteresowania badawcze: historia polityczna Polski po II wojnie światowej. E-mail: msiedziako@wp.pl. 